\title{
Patriarchal Myths in the Novels of Margaret Atwood: A Critical Study
}

\author{
Miss Huma \\ Research Scholar \\ Department of English \\ T.M. Bhagalpur University \\ Bhagalpur, India \\ humaafsar944@gmail.com
}

\begin{abstract}
The article acquaints and explains the consideration of Margaret Atwood's novels: 'Surfacing' (1972), 'The Handmaid's Tale' (1985), and 'The Robber Bride' (1993), which presents the role of patriarchal myths in the era of post-modern. She tried to represent the situation of women in contemporary society, where society demands mute acceptance from a woman considered as "weaker sex" or "inferior sex". Feminism both as a concept and a movement has emerged as a reaction against the atrocities of patriarchy. By myth-making, Margaret is testing her identity, perception, recording the world, and value systems projected is the past.
\end{abstract}

Keywords: Feminism, Myth, Patriarchy 
Introduction

Margaret Atwood is a Canadian writer and wrote many novels, short stories, and poetry. She is best known for her novel in which she represents the suffering of female character through a variety of genres and devices, most notably science fiction and reworking of myth. Most of her novels, Atwood focused to depict about patriarchal myths, among them the most famous novel Surfacing (1972), The Handmaid's Tale (1985), and The Robber Bride (1993), which present that the role of patriarchal myths in the post-modern era. Margaret Atwood's multifaceted collections of writing centre on feminist issues and concern. An appropriated the myth of freeloader in her text. The Robber Bride, where she challenges notions of gender and gender role in the dichotomy's term of 'good' and 'evil' through the mythic structure of consciousness. Atwood's purpose in appropriating the myth found to be almost similar to that of Russ and witting in that they too recreate a separate female space to create a 'self' in 'other' Atwood marginalized woman character in literary text too deprived of inner depth to their role. She portrayed as a virtuous character or passive or mute victim. She is never the agent or doer of action like her male counterparts' weather heroes or villains.

\section{Review of Literature}

Atwood explores to break away from the Victorian concept of 'Angel in the house' which even the woman's movement at one stage encloses as true female nature. Atwood views morality in terms of gender, to define as well while man as naturally bad. In her novel, the limited choice of woman character makes her uninteresting, if even they are bad occasionally, also in her novel. Some female characters did 'bad' things only for 
some 'good' reason thus to rescue woman character beings condemn eternally to 'virtue' and to break the monopoly of offensive behaviour enjoyment by men. Atwood takes up the responsibility of creating immortal female villains that literature has no far never witnessed.

Socialist Feminist and the Feminist Standpoint

As Atwood puts it: "Woman has more to the virtue, they are fully dimensional human beings, they too have subterranean depth, why shouldn't they many dimensionalities give literary expression", (Atwood 'Spotty-Handed,')

Socialist feminism is an attempt to illuminate the woman's situation in contemporary society, an attempt that rejects the abstract individualism of liberal political theory. The methodology and the epistemology are in favour of a theory of human nature that "structurally identical with that of traditional Marxism and the structure of its epistemology". It assumes that the standpoint of a woman, rooted in the sexual division of labour, not the sex blinded category of class, and important distinction- and using a revised version of alienation, can reveal a less distorted reality unavailable from the perspective of class alone, and one that theoretically at least, is available to men. Iris young points out that using the sexual division of labour rather than the class as an analytical category or crucial, because a class analysis calls for only the most abstract discussion of the respective roles of the bourgeoisie and the proletariat, whereas a division of labour analysis requires a detail, very concrete discussion of, for example, who gives the order and who takes them, who does the stimulating work and who does the drudge works, who works the desirable shift, and who works the undesirable shift, 
and who gets paid more and who gets paid less. Then, the division of labour analysis can better explain why a woman usually takes the order, do the drudge work, work the undesirable shift, and get paid less, while men usually give the order, do the stimulating work, the desirable shift, and get paid more. (Tong 1989, p-183-4)

\section{Power and Gender Identity}

Although Atwood has never defined herself as a feminist writer because of her conviction that a writer's works should remain outside the narrowing framework of all ideology, her writing offers feminist criticism invaluable material because it is about the female experience in western patriarchal society from a specifically female point of view. Among her novel Surfacing is the one that embodies the sharpest and most comprehensive critique of modern western culture and its constitutive myths. It is, therefore, not surprising that power, gender identity, and also madness emerged as the dominant theme and issues in this novel. We can see power structures that extend to matters of gender as the basic determinants that under gird a patriarchal society, while madness. Makes up space where the norms supporting power structure and the dominant gender ideology collapse, and are therefore symbolically subverted, Atwood explores in her novel how individuals become implicated in power relationships that often manifest themselves in domination and victimisation. However, Atwood's writing displays a profound awareness that involvement in a power structure often entails some internalisation of the ideology that reinforces that structure, and that individual is collaborators in the perpetuation of the assumptions that define their society. The changing ideology of gender assigns varying roles to men and women in different periods 
of history. Yet the essentialist assumption of a hierarchical difference between the sexes, the valorisation of masculinity over femininity seems to remain more or less constant in Surfacing, Atwood offers an unsettling questioning of what it means to be feminine and masculine in a culture already founded upon the basic division of subject and object, culture and nature. Within feminist scholarship, which is an interdisciplinary field of inquiry, the term gender stands for sexual identity as a social or cultural contract. It implies the totality of the social, cultural, and psychological meanings imposed on biologically given sex (Showalter 1989:1-2). Psychoanalytical theory becomes a useful tool for feminism in so far as it reveals sexual identity to be a social imposition deeply embedded in our psyche. According to Freud, sexual identity culturally enjoined and constantly resisted by the unconscious; it doesn't interiorise; in Lucan's term the unconscious, that other scene, refuses to submit to the symbolic order, the discipline of language and culture (Belsey and Moore. 1990:6)

Spatial and Psychophysical Domination of Woman in Dystopia

Analysing Atwood's The Handmaid's Tale, the article aims to examine the relations between spaces, gender-based violence, and patriarchy in a woman's writing. 'Gilead' in The Handmaid's Tale is a spatial and social nightmare. The authorities that rule these dystopian imprison women in restricted space first, limit their vocabulary and daily action, deprive them of their beauty, freedom, and consciousness, and pressure of maternity or sexuality upon them. My analysis will connect the limitation of space with the psychophysical domination of the objectification and the disempowerment of the female gender. Hoping also to shed light on the vigorous and the reasons for 
contemporary real gender-based violence and depreciation, the study will focus on the main points of Margaret Atwood's work like the approaches space contributes to the creation, the hardness, and the dominion of dystopian power the delegation and the construction of female figures, roles, and identities, the technique of control, manipulation and oppression used by a patriarchal power against woman, the impact of sex, sexuality and motherhood on woman's bodies and the possible feminist alternative or solution proposed by the novels. In Atwood's Surfaces, The Handmaid's Tale and The Robber Bride especially explain about sexism or prejudice. Sexism is discrimination based on a person's sex or gender. She says in her words that sexism can affect women and girls. It linked to stereotypes and gender roles and may contain the belief that one sex or gender is intrinsically superior to another. Extreme sexism may foster sexual harassment, rape, and other forms of sexual violence. Sometimes the situations of sexual harassment may exist in family too by which depression engulfs them and changes their psychology. Jahidul Azad aptly deduces the condition of women in family:

Women are deprived by the men. Their husbands are the persons who dominate them most. So the depression of the women symbolizes the men as monsters. It is usually very tough for any woman or man to sleep with the person who dominates her or him most. Women have to do it for the whole life so their depression knows no limit. (59)

Gender discrimination may encompass sexism and its intolerance explained in terms of workplace inequality, it may arise from social or cultural customs and nouns.

Psychological and Mythic Influences 
The Handmaid's Tale, like Atwood's earlier Surfacing, consumed by paranoia, and fuelled by the victim's edge of unease. But, 'Surfacing' is an exploration of a workable way out of victimisation. The Handmaid's Tale is the story of what victimisation feds like from the inside. This time there would seem to be no existence in 'Surfacing' the narrator has to descend into a kind of primitive essentials in her quest for power, integrity, and feminine accused. 'Offred' in The Handmaid's Tale, while more impersonal than that narrator, has the fully developed desire and voice she never achieved. What 'Offered' lacks, however, is the ability to act, to rescue herself or her loved ones. Without that power, her voice and desire remains irrelevant. In 'Surfacing' the heroine's lack of spirit, we linked her sense of herself as less than whole to her powerlessness, her sense of herself as a victim. 'Offred', in contrast, is very much a fully formed subject with a powerful sense of voice and desire, who endures victimises by events beyond her control. This is a spectacle much more frightening, the narrator of surfacing learned, or appeared to learn, that to relinquish power (language, voice, and desire) is to accept the role of passive victim. In 'The Handmaid's Tale' 'Offred' lives the role of victim with voice and desire intact and fully formed. They provide her, however, with no more access to power than that experienced by the woman is Surfacing 'offered' then. Women differ very little from her predecessors, Isabel, Hester, Clarissa, and Tess. All are vigorous women held in ways beyond their control, whose only power is the power to move others. However, in The Handmaid's Tale, unlike the earlier novel, the emotion constructed for us to feel is not so much love or sympathy as pain and outrage, dull despair. In Surfacing there is a sense, however tentative that the narrator might have learned to power and use it for herself, in The Handmaid's Tale we find that Offred's use 
of power is no further developed, and is even more restricted. Again, I will look at this novel in terms of the three categories: desire, voice, and female rescue/heroism. Linda Kauffman writes that "Offred narrates from exile, a ceaseless reiteration of her desire and her despair. I would like to examine the connection between those two terms. Desire in The Handmaid's Tale appears to be a quantifiable substance. Its origin is mysterious, and its creation. Instead, it seems to be just there Desire exists before despair and despair, only augments its" According to Atwood's novel 'The Robbers Bride' explains such a balanced model is particularly lacking in traditional discussions of women's sexual desire. Instead of the Freudian/Oedipal emphasis on the experience within the psyche ('the intra-psychic mode' of representation) in which the phallus equated with power, separation, and individuality and woman subsequently defined in terms of what they, Atwood posits the relevance of the inter-subjective dimension which considers “experience between and within individuals, rather than just within" and where two subject meets; thus not only man but also a woman can be subject. Atwood argues that this inter-subjective views of a woman's desire can be better expressed "in spatial rather than a symbolic representation" The psychological connection between domination and submission erotic love, modelled infant (other) interaction, and the importance of narrating one's own life story is powerfully represented in The Robber Bride. The novel begins with the three protagonists in middle age suddenly re-encountering the protagonist's earlier traumatic involvements with the chameleon-like storytellers. Atwood says that a woman's body in the analyzed novels, and often in real life, is externally masculine power, to be practical, obey, and serve an economic use as De Beauvoir affirms: "one is not born, but rather becomes, a woman. No biological, psychic, 
or economic destiny defines The figure that the human female takes on in society; It is civilization as a whole that elaborates this intermediary product between the male and the eunuch that Is called feminine" Patriarchal societies in fiction and history have been absorbed with sexuality and purity. The "virgin-whore complex" has profoundly influenced the affirmation of female gender and still does despite cultural, religious, and political differences depending on time and place, an ideal woman has often been depicted as a pure, passive, and nurturing figures (virgin) while independent and sexually liberated model of femininity has usually been interpreted as negative and dirty (whore). Manhood, instead, has always been linked to active and dominant attributes, roles, and behaviours, to the idea that men are in charge of society, while a woman's identity is strictly connected with domesticity, maternity, and submission. A woman only accepts the patriarchal structure and always oppressed by a man. Social conditions always compel her to follow the preset structure based on patriarchal norms. These norms transfer power to male enhancing the male-oriented outlook and justify the supremacy of man over woman. In a male dominated society a woman is oppressed by different angles because of the tendency of practising violence against woman. This violence can be physical or psychological. Messaoudi Wali points out that "patriarchy is violence if it is not physically, so it is psychologically and it effects the weak or the victim. "(66) Fabric of society is an outcome of different families and a family is a group of individuals. In this sense "male dominance can be from a brother towards sister or even from brother towards mother" (66) 


\section{Conclusion}

Silenced, abused, controlled, and manipulated, the woman in 'The Robber Bride', 'The Handmaid's Tale' and 'Surfacing' where patriarchal myths and dystopias' hit the hardest and remind us what we defend; our spaces, our choices, regard our bodies and our expression. These novels tell with lucidity, passion, and pain how female social exclusion linked to the limitation of spaces and mobility and how the female body can become a political vessel and an object to promote impose a patriarchal, conservative and repressive authority. These stories of women remind us of how dangerous some discourses can be and how easily democracy can collapse or reveal its "dystopian" traits. In a piece about The Handmaid's Tale, Atwood wrote for the Guardian; "I made a rule for myself, I would include nothing that human being had already done in some other place or time I did not wish accused of dark, twisted invention, or of misrepresenting the human potential for deplorable behaviour". Women cannot even cry. We consider her crying as a rebellion. 


\section{References}

Atwood, Margaret. Surfacing. Toronto: McClelland and Stewart, 1972. Print

Atwood, Margaret. 1989. The Handmaid's Tale. Toronto: seal- McClelland Bantam.

Atwood, M. 1986. The Handmaid's Tale. Toronto: McClelland and Stewart-Bantam.

Atwood, Margaret. Moving targets: Writing with Intent, 1982-2004. Toronto: Anansi Press, 2004

Atwood, Margaret. The Robber Bride. London: Virago Press, 2002. Print.

Azad, M. J. (2019). Female Depression Through Symbolism: A Study on the Selected Poems of Adrienne Rich. International Journal Online of Humanities, 5(6), 5261. doi.org/10.24113/ijohmn.v5i6.150

Beauvoir, Simone de (2009) [1949]. The second sex. Trans. Constance Borde and Sheila Malovany Chevallier. Random House.

Christ C P. 1976. Margaret Atwood: the Surfacing of woman's spiritual Quest and Vision.

Cooke, N. 2004. Margaret Atwood. A critical companion. London: Greenwood Press.

Walid, M. (2019). Patriarchy, Oppression and Illegal Migration in Leila Lalami’s Collection of Short Stories "Hope and Other Dangerous Pursuits". International Journal Online of Humanities, 5(5), 62-72. doi.org/10.24113/ijohmn.v5i5.140 